\title{
Rate of fertilization in vitro and subsequent nuclear development as a function of the post-ovulatory age of the mouse egg
}

\author{
Lynn R. Fraser* \\ Clinical Research Centre, Watford Road, Harrow, Middlesex, London, U.K.
}

\begin{abstract}
Summary. Evidence is presented to indicate that older mouse eggs are fertilized more rapidly and also develop more rapidly to the pronuclear stage than younger ones. After a low (1.5 i.u.) or a high (7.5 i.u.) dose of PMSG, female mice were killed 13 or $17 \mathrm{~h}$ after hCG. The eggs were mixed in vitro with preincubated spermatozoa and fixed $1-1 \frac{1}{4} \mathrm{~h}$ later. Although fertilization levels were high in all groups, the stages of egg activation and sperm head decondensation differed significantly. The observed ranking, from most to least rapid fertilization, of eggs obtained from females treated with 7.5 i.u. and killed $17 \mathrm{~h}$ after hCG, 1.5 i.u. and $13 \mathrm{~h}$, and $7.5 \mathrm{i} . \mathrm{u}$. and $13 \mathrm{~h}$, was consistent with the approximate length of time the eggs had resided in the oviduct, i.e. the longer that time period, the more rapid the fertilization. When eggs were fixed $4 \frac{1}{4}$ $\mathrm{h}$ after mixing with spermatozoa, the majority of older eggs were fully pronuclear while only a few of the younger eggs were as advanced, indicating accelerated nuclear development in the cytoplasm of the older eggs.
\end{abstract}

\section{Introduction}

Results from a number of studies in which the relationship between mating and fertilization has been examined have suggested that there is a delay of sperm penetration into freshly ovulated rodent eggs, although such a delay has not been found for some other species, e.g. the rabbit (Austin \& Braden, 1954) and pig (Hunter \& Dziuk, 1968). While the length of the delay has varied among experiments as well as species, the phenomenon has been reported for rats (Austin \& Braden, 1954), hamsters (Austin, 1956; Strauss, 1956; Yanagimachi, 1966) and mice (Braden \& Austin, 1954; Edwards \& Gates, 1959). In experiments in which mating preceded ovulation, sperm capacitation should have been completed by the time the freshly ovulated eggs reached the oviduct, and yet fertilized eggs were not immediately recovered. When mating occurred after ovulation, with the eggs residing in the oviduct for some time, the delay observed was shorter and presumably represented the time required for sperm capacitation.

In-vivo experiments such as those just cited have several limitations. In particular, ovulation, either spontaneous or hormonally induced, occurs over a span of several hours (e.g. in the mouse: Braden \& Austin, 1954; Donahue, 1972; Krishna \& Generoso, 1977) and therefore the population of eggs is a changing one. Furthermore, conditions within the female reproductive tract several hours after ovulation may well differ from those before ovulation and hence sperm reactions may also vary. In the present experiments an in-vitro system was used in which eggs of different post-ovulatory ages were mixed with capacitated spermatozoa and then fixed at various times to permit precise assessment of (a) fertilization, (b) female nuclear development, and (c) male nuclear development in relation to the age of the egg, and thus provide a comparison of sperm penetration rates.

* Present address: Department of Human Biology, Basic Medical Sciences Group, Chelsea College, Manresa Road, London SW3 6LX, U.K. 


\section{Materials and Methods}

\section{In-vitro fertilization}

Adult (2-4 months old) virgin outbred TO females in metoestrus or early dioestrus (Champlin, Dorr \& Gates, 1973) were induced to ovulate by injections of 1.5 or 7.5 i.u. PMSG (Gestyl: Organon), followed by 5.0 i.u. hCG (Pregnyl: Organon) approximately $48 \mathrm{~h}$ later. The females were killed at various times after hCG injection for recovery of unfertilized eggs. To permit use of the same initial sperm suspensions, females were injected asynchronously with hCG when necessary. Epididymal sperm suspensions were prepared from TO males (Fraser \& Drury, 1975) and preincubated at $37^{\circ} \mathrm{C}$ for $2 \mathrm{~h}$ to allow completion of capacitation (Fraser \& Drury, 1976) before eggs were introduced. The sperm suspensions were then diluted to $2 \times 10^{6}$ spermatozoa $/ \mathrm{ml}$ and unfertilized eggs were added.

A few minutes before fixation, eggs were removed from the sperm suspensions, washed briefly and transferred to droplets of culture medium under paraffin oil (Boots). At the appropriate time, most of the medium was withdrawn from each droplet and replaced with buffered formalin. This procedure allowed fixation of several groups of eggs within a few seconds of each other. After fixation, the eggs were stained with $0.5 \%$ aceto-orcein and examined for resumption of meiosis II and decondensation of the fertilizing sperm head.

In the first set of experiments (Series 1), eggs ovulated in response to 1.5 and 7.5 i.u. PMSG and recovered $13 \mathrm{~h}$ after $\mathrm{hCG}$, and to 7.5 i.u. PMSG and recovered $17 \mathrm{~h}$ after hCG, were examined $1 \mathrm{~h}$ after mixing with spermatozoa. In the second set of experiments (Series 2), eggs ovulated in response to 7.5 i.u. PMSG and recovered 13 and $17 \mathrm{~h}$ after hCG were examined. These eggs were fixed $1 \mathrm{~h} 15 \mathrm{~min}$ and $4 \mathrm{~h} 15 \mathrm{~min}$ after gamete mixing, the latter permitting assessment of pronuclear development.

\section{Assessment of sperm and egg nuclear development}

In the eggs fixed after $1 \mathrm{~h}, 4$ stages of activation were noted in those which had resumed meiosis II: (1) very early anaphase at which the chromatids were just beginning to separate; (2) early anaphase where there was definite separation of chromatids; (3) middle-late anaphase, indicated by progression of chromatids half the distance or more towards the poles of the spindle; (4) telophase, shown by the typical clustering of chromatids at the poles of the spindle. In eggs fixed after $1 \mathrm{~h} 15 \mathrm{~min}$, there were few at very early anaphase, but a sizeable proportion had the second polar body.

In both groups of eggs, three stages of sperm head decondensation were noted: (1) just beginning to decondense; (2) approximately half decondensed; (3) fully decondensed with heavy stain only at the sperm neck. These three stages are essentially those denoted as Types I-III by McGaughey \& Chang (1969) and easily recognizable.

In eggs fixed after $4 \mathrm{~h} 15 \mathrm{~min}$, nuclear development was considerably advanced and 4 different stages were noted: (1) arrested or very late fertilization; (2) pre-pronuclear with female nuclear material still present in chromatin form; (3) pronuclei just forming and being small with obvious staining of the nucleoplasm; (4) pronuclear, i.e. definite pronuclei with 1 or more nucleoli and little staining of the nucleoplasm.

\section{Timing of ovulation}

In an additional experimental series, TO females were killed at various times after the hCG injection to determine the rate of which eggs were released into the oviduct after different degrees of hormonal stimulation, i.e. 1.5 or 7.5 i.u. PMSG. At least 3 females were examined for each time, but generally 5-8 were used for those near the time of completion of ovulation. For 
comparison, similar determinations were made on $(\mathrm{C} 57 \mathrm{BL} / 10 \times \mathrm{CBA}) \mathrm{F}_{1}$ females treated with 7.5 i.u. PMSG. The mean times after hCG when ovulation had been completed in the three groups were compared.

\section{Results}

\section{Series $I$}

From the results presented in Table 1 , it is evident that within $1 \mathrm{~h}$ of gamete mixing, most eggs, whether stimulated with a low or a high dose of PMSG and recovered 13 or $17 \mathrm{~h}$ after hCG, were fertilized (range 78-83\%). On the other hand, the proportion of eggs at different stages of activation varied considerably among the three groups. The majority of eggs in Group B $(86 \%)$ were only at some stage of early anaphase, while most eggs in Group C $(68 \%)$ were at later stages $\left(\chi^{2}, P<0.001\right)$. The eggs in Group A showed slower development than those in Group C $(P<0.01)$ and faster development than those in Group B $(P<0.001)$. These groups can be placed in the order $\mathrm{C}>\mathrm{A}>\mathrm{B}$ on the basis of the degree of development of the eggs. In each of the 4 individual experiments in this series this ranking was observed, with the Group $C$ eggs being fertilized sooner than the others.

Table 1. The in-vitro fertilization results of eggs recovered 13 and $17 \mathrm{~h}$ after hCG injection from TO female mice, induced to superovulate with 1.5 and 7.5 i.u. PMSG, and mixed with preincubated epididymal TO spermatozoa for $1 \mathrm{~h}$

\begin{tabular}{|c|c|c|c|c|c|c|c|c|c|c|}
\hline \multirow[b]{2}{*}{ Group } & \multirow[b]{2}{*}{ Treatment } & \multirow[b]{2}{*}{$\begin{array}{l}\text { No. of } \\
\text { exps. }\end{array}$} & \multirow[b]{2}{*}{$\begin{array}{c}\text { Eggs } \\
\text { fertilized }\end{array}$} & \multicolumn{4}{|c|}{ Egg stage ${ }^{*} \dagger$} & \multicolumn{3}{|c|}{ Sperm head stage } \\
\hline & & & & $\begin{array}{l}\text { Very early } \\
\text { anaphase }\end{array}$ & $\begin{array}{c}\text { Early } \\
\text { anaphase }\end{array}$ & $\begin{array}{l}\text { Mid-late } \\
\text { anaphase }\end{array}$ & Telophase & 1 & 2 & 3 \\
\hline A & $\begin{array}{c}1.5 \text { i.u. PMSG, } \\
13 \mathrm{~h}\end{array}$ & 4 & $\begin{array}{l}78 / 100 \\
(78 \%)\end{array}$ & $\begin{array}{c}25 \\
(32 \%)\end{array}$ & $\begin{array}{c}17 \\
(22 \%)\end{array}$ & $\begin{array}{c}24 \\
(30 \%)\end{array}$ & $\begin{array}{c}12 \\
(15 \%)\end{array}$ & $94 \%$ & $4 \%$ & $1 \%$ \\
\hline B & $\begin{array}{c}7.5 \text { i.u PMSG, } \\
13 \mathrm{~h}\end{array}$ & 4 & $\begin{array}{c}127 / 159 \\
(80 \%)\end{array}$ & $\begin{array}{c}79 \\
(62 \%)\end{array}$ & $\begin{array}{c}31 \\
(24 \%)\end{array}$ & $\begin{array}{c}16 \\
(13 \%)\end{array}$ & $\begin{array}{c}1 \\
(1 \%)\end{array}$ & $100 \%$ & - & - \\
\hline $\mathrm{C}$ & $\begin{array}{c}7 \cdot 5 \text { i.u. PMSG, } \\
17 \mathrm{~h}\end{array}$ & 4 & $\begin{array}{l}92 / 111 \\
(83 \%)\end{array}$ & $\begin{array}{c}16 \\
(17 \%)\end{array}$ & $\begin{array}{c}13 \\
(14 \%)\end{array}$ & $\begin{array}{c}39 \\
(42 \%)\end{array}$ & $\begin{array}{c}24 \\
(26 \%)\end{array}$ & $80 \%$ & $19 \%$ & $1 \%$ \\
\hline
\end{tabular}

* Of those fertilized.

$\uparrow$ See text for detailed description of stages.

These differences in stage of egg activation were mirrored in the differences observed in sperm head changes. All sperm heads in the Group B eggs were at stage 1, while there were a few at stages 2 and 3 in the Group A eggs and $20 \%$ of sperm heads had advanced to stages 2 and 3 in Group C. Although sperm heads at stages 2 and 3 were only observed in Group A eggs which had reached telophase, $23 \%$ of the stage 2 sperm heads in Group C eggs were found at the midlate anaphase stage. In all groups, stage 3 was associated only with eggs at telophase.

The results in Table 2 indicate that, in general, ovulation was maximal $13 \mathrm{~h}$ after hCG in TO females treated with 1.5 i.u. PMSG but not until $14 \mathrm{~h}$ when 7.5 i.u. PMSG were given. While ovulation was not completed until $14 \mathrm{~h}$ after $\mathrm{hCG}$ in TO females receiving $7 \cdot 5$ i.u. PMSG, the $\mathrm{F}_{1}$ females receiving the same high dose had responded maximally by $12.5 \mathrm{~h}$ after hCG (Table 2 ). These two strains also differed in the number of eggs shed, with a mean of 43 ovulated by TO and 25 by $F_{1}$ females. A dose of 7.5 i.u. PMSG/female has previously been shown to induce the optimal ovulatory response in these two strains (Fraser, 1977).

\section{Series $I I$}

In these experiments there was again a significant difference $(P<0.001)$ in the proportion of eggs at late stages of activation (telophase-polar body 2), with eggs obtained $17 \mathrm{~h}$ after hCG again being more advanced when assessed by both egg stage and sperm head stage (Table 3 ). 
Table 2. Ovulation rates (mean no. of eggs/female with range in parentheses) in $\mathrm{TO}$ and $(\mathrm{C} 57 \mathrm{BL} / 10 \times \mathrm{CBA}) \mathrm{F}_{1}$ females, induced to superovulate with 1.5 or 7.5 i.u. PMSG and 5.0 i.u. hCG, determined by collection at different times after hCG

\begin{tabular}{cccc}
\hline $\begin{array}{c}\text { Mouse } \\
\text { strain }\end{array}$ & Time after hCG (h) & 1.5 i.u. PMSG & $7 \cdot 5$ i.u. PMSG \\
\hline \multirow{2}{*}{ TO } & 12 & $8 \cdot 4(0-21)$ & $8 \cdot 0(0-29)$ \\
& 13 & $14 \cdot 8(1-37)$ & $27 \cdot 1(0-43)$ \\
& 14 & $15 \cdot 5(10-31)$ & $38 \cdot 0(33-46)$ \\
& 15 & $16 \cdot 6(6-26)$ & $41.4(23-53)$ \\
& 16 & $15 \cdot 0(8-20)$ & $47.5(41-54)$ \\
$F_{1}$ & 17 & $13 \cdot 3(11-19)$ & $46 \cdot 2(35-65)$ \\
& 11 & - & $6 \cdot 6(1-13)$ \\
& 11.5 & - & $16 \cdot 4(1-27)$ \\
& 12 & - & $19 \cdot 0(8-30)$ \\
& $12 \cdot 5$ & - & $25 \cdot 5(17-35)$ \\
& 13 & - & $24 \cdot 7(18-36)$ \\
& 14 & & \\
\hline
\end{tabular}

The differences were even more striking when eggs from the same groups were fixed $4 \mathrm{~h} 15 \mathrm{~min}$ after gamete mixing (Table 4 ); $71 \%$ of the embryos in the older group were pronuclear compared with only $10 \%$ in the younger group. Most of the embryos in the 13 -h group had not begun to form recognizable pronuclei and, in particular, the female nuclear material was still present as a chromatin mass (stage 2 ). In the embryos at stage 3 , the forming male pronucleus was generally still located in the cortical region and frequently caused a distinct bulge in the egg, similar to the "fertilization cone" in invertebrates (Austin \& Braden, 1956). These bulges made easily recognizable diagnostic features, because when they were no longer detectable the embryos generally possessed fully formed pronuclei.

When present, the two pronuclei were readily distinguishable as male and female by size, position and the location of the sperm tail. The male pronucleus was larger and had several nucleoli; the typical female pronucleus in younger eggs had a single large nucleolus $(1 \cdot 2 /$ pronucleus) but those in older eggs usually had several smaller nucleoli ( $2 \cdot 3 /$ pronucleus). Similarly, there were more nucleoli/male pronucleus in the older than in the younger eggs $(9.7$ versus 6.9$)$. The female pronucleus was usually located near the second polar body, the nuclear organization of which was very similar to that in the female pronucleus, with one or more structures resembling nucleoli. The sperm tail was found near, but not necessarily attached to, the male pronucleus.

Table 3. The in-vitro fertilization results of eggs recovered 13 and $17 \mathrm{~h}$ after hCG injections from TO females, induced to superovulate with 7.5 i.u. PMSG, and mixed with preincubated epididymal TO spermatozoa for $1 \mathrm{~h} 15 \mathrm{~min}$

\begin{tabular}{|c|c|c|c|c|c|c|c|c|c|}
\hline \multirow[b]{2}{*}{ Group } & \multirow[b]{2}{*}{$\begin{array}{l}\text { No. of } \\
\text { exps. }\end{array}$} & \multirow[b]{2}{*}{$\begin{array}{c}\text { Eggs } \\
\text { fertilized }\end{array}$} & \multicolumn{4}{|c|}{ Egg stage* } & \multicolumn{3}{|c|}{ Sperm head staget } \\
\hline & & & $\begin{array}{c}\text { Early } \\
\text { anaphase }\end{array}$ & $\begin{array}{l}\text { Mid-late } \\
\text { anaphase }\end{array}$ & Telophase & $\begin{array}{l}\text { Polar } \\
\text { body } 2\end{array}$ & 1 & 2 & 3 \\
\hline $13 \mathrm{~h}$ & 3 & $\begin{array}{c}142 / 169 \\
(84 \%)\end{array}$ & $\begin{array}{c}14 \\
(10 \%)\end{array}$ & $\begin{array}{c}29 \\
(20 \%)\end{array}$ & $\begin{array}{c}86 \\
(60 \%)\end{array}$ & $\begin{array}{c}13 \\
(10 \%)\end{array}$ & $49 \%$ & $32 \%$ & $19 \%$ \\
\hline $17 \mathrm{~h}$ & 3 & $\begin{array}{c}130 / 155 \\
(84 \%)\end{array}$ & $\begin{array}{c}4 \\
(3 \%)\end{array}$ & $\begin{array}{c}13 \\
(10 \%)\end{array}$ & $\begin{array}{c}90 \\
(69 \%)\end{array}$ & $\begin{array}{c}23 \\
(18 \%)\end{array}$ & $25 \%$ & $43 \%$ & $33 \%$ \\
\hline
\end{tabular}

* Of eggs fertilized.

+ See text for detailed description of stages. 
Table 4. The in-vitro fertilization results of eggs recovered 13 and $17 \mathrm{~h}$ after hCG injection from TO females, induced to superovulate with 7.5 i.u. PMSG, and mixed with preincubated epididymal TO spermatozoa for $4 \mathrm{~h} 15 \mathrm{~min}$

\begin{tabular}{|c|c|c|c|c|c|c|c|c|}
\hline \multirow[b]{2}{*}{ Group } & \multirow[b]{2}{*}{$\begin{array}{l}\text { No. of } \\
\text { exps. }\end{array}$} & \multirow[b]{2}{*}{$\begin{array}{c}\text { Eggs } \\
\text { fertilized* }\end{array}$} & \multicolumn{4}{|c|}{ Stage } & \multicolumn{2}{|c|}{ Nucleoli/pronucleus } \\
\hline & & & Pronuclear & $3+$ & $2+$ & $1+$ & $\sigma^{\pi}$ & q \\
\hline $13 \mathrm{~h}$ & 3 & $\begin{array}{c}201 / 222 \\
(91 \%)\end{array}$ & $\begin{array}{l}18 / 180 \\
(10 \%)\end{array}$ & $\begin{array}{c}57 / 180 \\
(32 \%)\end{array}$ & $\begin{array}{c}100 / 180 \\
(56 \%)\end{array}$ & $\begin{array}{c}5 / 180 \\
(4 \%)\end{array}$ & $6 \cdot 9$ & 1.2 \\
\hline $17 \mathrm{~h}$ & 3 & $\begin{array}{c}169 / 196 \\
(86 \%)\end{array}$ & $\begin{array}{c}85 / 119 \\
(71 \%)\end{array}$ & $\begin{array}{c}28 / 119 \\
(24 \%)\end{array}$ & $\begin{array}{l}2 / 119 \\
(2 \%)\end{array}$ & $\begin{array}{c}4 / 119 \\
(3 \%)\end{array}$ & 9.7 & $2 \cdot 3$ \\
\hline
\end{tabular}

* Eggs with second polar body/total eggs; assessed before fixation.

$\leftarrow$ See text for detailed description.

Although polyspermic embryos were observed, the whole-mount preparations used in this study made complete accuracy in detecting extra spermatozoa difficult; this was particularly true for eggs fixed $1 \mathrm{~h}$ after mixing with spermatozoa. Many spermatozoa were still adhering to the zona and interfered with observations. When 2 sperm heads were present, they were at the same stage of decondensation and were generally close together or $180^{\circ}$ apart. In the later embryonic stages, there were no obvious differences between the old and young eggs, with polyspermy (primarily dispermy) ranging from 8 to $11 \%$. Such figures are consistent with results from chromosomal preparations of first cleavage embryos, but the latter method (Maudlin \& Fraser, 1977) is preferable for exact determinations

\section{Discussion}

As detailed in the 'Introduction', the existence of a delay in sperm penetration into recently ovulated rodent eggs has been inferred from results of various in-vivo mating studies. The invitro experiments presented here clearly demonstrate that such a difference does occur, sperm penetration being significantly faster into eggs which have resided in the oviduct for 1 or more hours than into more recently ovulated eggs. The time differential detected, although unequivocal, was not more than about 30 min since most eggs capable of being fertilized had been fertilized within $1 \mathrm{~h}$. This is a shorter period than in-vivo matings of mice have suggested, i.e. 1-3 h (Braden \& Austin, 1954; Edwards \& Gates, 1959). Such differences probably reflect the fact that an in-vitro system can immediately test the eggs themselves, while in vivo there are restrictions on accuracy imposed by the spread in ovulation, and hence a change in the population of eggs during the course of the experiment, and a possible limiting concentration of spermatozoa. Because of this, an in-vitro system has several advantages over an in-vivo system for such a study. First, the spermatozoa can be fully capacitated at the start of the experiment and interference from changing conditions in the female tract can be eliminated; thus different groups of eggs can be tested simultaneously with the same sperm suspension. Second, the sperm concentration is known to be adequate to ensure fertilization, if indeed the eggs can be fertilized. Third, the relationship between the time of hCG injection and recovery of eggs is precisely known and only a fixed pool of eggs is used in each group. Fourth, the timing of gamete interactions can be controlled exactly. The results from in-vivo matings are necessarily less exact on each of these points.

In the present experiments, the eggs obtained from TO females $17 \mathrm{~h}$ after hCG would have been in the oviduct for at least $3 \mathrm{~h}$, while at $13 \mathrm{~h}$ the residence would have been about $1 \mathrm{~h}$ and $<1 \mathrm{~h}$ for the majority of eggs obtained from females treated with 1.5 and 7.5 i.u. PMSG, respectively. The observed differences among the eggs (Group C > Group A > Group B, 
Table 1) correlate well with the approximate length of residence in the oviduct. The results from both series of experiments (Tables 1 and 3) demonstrate that older eggs are fertilized more rapidly, as evidenced by more advanced stages of egg activation and sperm head decondensation. Development to the pronuclear stage also occurred more rapidly in older eggs: $1 \mathrm{~h}$ after gamete mixing stage 2 (half-decondensed) sperm heads were found in older eggs at mid-late anaphase, while advanced stages of sperm decondensation in young eggs were only found in assocation with the telophase stage and only stage 1 heads were found with the earlier egg stages. More striking differences were noted $4 \mathrm{~h} 15$ min after mixing of gametes since most of the older eggs were pronuclear, compared with only a small proportion in the younger group. The pronuclei in the former were also presumed to be older since the mean number of nucleoli per pronucleus was greater for both male and female pronuclei; such an increase in nucleolar number has been shown to occur as pronuclear age advances (Austin, 1961).

Studies of oocyte maturation in vitro in several mammalian species have indicated that nuclear maturation, i.e. completion of meiosis I with extrusion of the first polar body, can be achieved fairly easily, but does not necessarily yield oocytes capable of normal fertilization and development; frequently the cytoplasm of such oocytes fails to promote decondensation and development of the fertilizing sperm head (Thibault, Gerard \& Menezo, 1975). Furthermore, the pattern of proteins synthesized by these oocytes may fail to change in the manner observed during maturation in vivo, suggesting only partial cytoplasmic maturation (Warnes, Moor \& Johnson, 1977). When maturation in vivo in the hamster is triggered by administration of hCG and eggs are fertilized at different stages of maturation, it is evident that the ability of the oocyte cytoplasm to promote male pronuclear formation increases as maturation proceeds and continues after completion of maturation, since mature oviductal eggs promote faster pronuclear development than mature ovarian eggs (Usui \& Yanagimachi, 1976). The experimental results presented here, obtained with mature oviductal mouse eggs, are consistent with the above findings and, furthermore, indicate a continued increase even after ovulation in the rate at which the oocyte cytoplasm promotes pronuclear development.

From these results it is possible to calculate the approximate time required for various stages of early embryonic nuclear development. Braden \& Austin (1954) have reported that potentially fertilizing spermatozoa remain in the perivitelline space for approximately 30 min before fusing with the plasma membrane, while Edwards \& Gates (1959) reported a mean time of $50 \mathrm{~min}$. In the present experiments the former figure would seem more likely since by $1 \mathrm{~h}$ after gamete mixing most of the eggs recovered $17 \mathrm{~h}$ after $\mathrm{hCG}$ were at late anaphase-telophase of meiosis II; this would allow about $30 \mathrm{~min}$ for the anaphase-telophase transition and then another 15-30 min for extrusion of the second polar body. Such figures are consistent with results reported by Iwamatsu \& Chang (1970) and Toyoda, Yokoyama \& Hosi (1971). Since the time required for pronuclear formation is dependent on the age of the egg at fertilization, the time required for pronuclei to form in the eggs recovered $17 \mathrm{~h}$ after hCG was approximately $3 \mathrm{~h}$ after the estimated time of fertilization, while the figure for the younger eggs ( $13 \mathrm{~h}$ after $\mathrm{hCG}$ ) would be about $4 \mathrm{~h}$ or more. These findings are also consistent with those of various in-vivo studies in which the time required for pronuclear development could be estimated. In general, studies utilizing normal mating, i.e. preceding ovulation with consequent fertilization of young eggs, suggested times of $>4 \mathrm{~h}$ (Edwards \& Gates, 1959; Donahue, 1972), longer than those of approximately 3-4 h obtained with delayed mating, i.e. following ovulation with fertilization of older eggs (Braden \& Austin, 1954: McGaughey \& Chang, 1969; Krishna \& Generoso, 1977).

In the experiments presented here there was no indication that the $17 \mathrm{~h}$ eggs were ageing appreciably. The cumulus layers were still intact and there were no visible signs that the cumulus clots were beginning to break up into individual eggs. Furthermore, the eggs were definitely fertilized and not parthenogenetically activated, as may occur when aged eggs are introduced into a sperm suspension (Kaufman, 1973). Unlike the eggs from some inbred strains, the eggs of TO mice are resistant to activation, even when recovered $22 \mathrm{~h}$ or more after hCG (L. R. Fraser, unpublished observation). 
Striking differences in the rate of ovulation were observed in the $F_{1}$ and TO females stimulated with 7.5 i.u. PMSG, with ovulation in the former being completed $12.5 \mathrm{~h}$ after hCG, $1.5 \mathrm{~h}$ earlier than in the TO counterparts. This result emphasizes that what is a 'young' egg in one strain is not necessarily 'young' in another, a fact which could be important, for example, when using an in-vitro system in which egg donors are killed at a single fixed time after hCG. From the data presented here, one would predict rapid fertilization of $F_{1}$ eggs recovered $13 \mathrm{~h}$ after hCG and this is indeed the case (L. R. Fraser, unpublished observation).

There are several possible explanations for the slower penetration of spermatozoa into young eggs. In order to achieve fertilization, spermatozoa must deal with three barriers: the cumulus cells, the zona pellucida and the egg plasma membrane. Braden (1962) has suggested that the cumulus cells must undergo some type of maturation after ovulation before spermatozoa can interact successfully. Certainly the cumulus layer does undergo visible changes within the follicle for it is there that the matrix, primarily hyaluronic acid, is laid down (Austin, 1961). Occasionally, oviductal eggs are recovered which never lose their cumulus cells in the present invitro system, even after $6 \mathrm{~h}$ in a sperm suspension. The cells are very tightly adherent to such eggs and these eggs are found to be unfertilized if the cumulus cells are dissected away (L. R. Fraser, unpublished observation). Although it is likely that these eggs have been released prematurely from follicles and hence are not fully mature, it is possible that some final modifications normally occur within the oviduct. Likewise, the zona might undergo some modification after ovulation and before fertilization, although there is, at present, no evidence for such a change. Finally, the oocyte plasma membrane may have to undergo particular postovulatory changes before fusion can be achieved. For example, the number of cortical granules present in mouse eggs increases after ovulation and it is possible that a minimum population of cortical granules is required before fertilization can be achieved (Zamboni, 1970). Against this are the numerous observations from in-vivo matings of young eggs that were not penetrated, i.e. spermatozoa had not yet passed through the zona pellucida into the perivitelline space; hence, the barrier would appear to be at the cumulus or zona level and not the plasma membrane.

The present results do not discriminate among these possibilities, but they do show that such an in-vitro system in which the conditions can be precisely controlled can provide a highly synchronous population of embryos at very early stages of development which could prove invaluable in investigations of very early embryonic changes.

\section{References}

Austin, C.R. (1956) Ovulation, fertilization and early cleavages in the hamster (Mesocricetus auratus). $J$. R. microsc. Soc. 75, 141-154.

Austin, C.R. (1961) The Mammalian Egg. Blackwell Scientific Publications, Oxford.

Austin, C.R. \& Braden, A.W.H. (1954) Time relations and their significance in the ovulation and penetration of eggs in rats and rabbits. Aust. J. Biol. Sci. 7, 179-194.

Austin, C.R. \& Braden, A.W.H. (1956) Early reactions of the rodent egg to spermatozoon penetration. $J$. exp. Biol. 33, 358-365.

Braden, A.W.H. (1962) Spermatozoon penetration and fertilization in the mouse. Symp. genet. Biol. Italica, Pavia, Italy, 9, 1-9.

Braden, A.W.H. \& Austin, C.R. (1954) Fertilization of the mouse egg and the effect of delayed coitus and of hot-shock treatment. Aust. J. biol. Sci. 7, 552-565.

Champlin, A.K., Dorr, D.L. \& Gates, A.H. (1973) Determining the stage of the estrus cycle in the mouse by the appearance of the vagina. Biol. Reprod. 8, 491-494.
Donahue, R.P. (1972) Fertilization of the mouse oocyte: sequence and timing of nuclear progression to the two-cell stage. J. exp. Zool. 180, 305-318.

Edwards, R.G. \& Gates, A.H. (1959) Timing of the stages of maturation divisions, ovulation, fertilization and the first cleavage of eggs of adult mice treated with gonadotrophins. J. Endocr. 18, 292-304.

Fraser, L. R. (1977) Fertilization and preimplantation development in vitro of mouse eggs obtained following stimulation with different doses of pregnant mare serum. Differentiation 9, 29-35.

Fraser, L.R. \& Drury, L.M. (1975) The relationship between sperm concentration and fertilization in vitro of mouse eggs. Biol. Reprod. 13, 513-518.

Fraser, L. R. \& Drury, L.M. (1976) Mouse sperm genotype and the rate of egg penetration in vitro. $J$. exp. Zool. 197, 13-20.

Hunter, R.H.F. \& Dziuk, P.J. (1968) Sperm penetration of pig eggs in relation to the timing of ovulation and insemination. J. Reprod. Fert. 15, 199-208.

Iwamatsu, T. \& Chang, M.C. (1970) Further investigations of capacitation of sperm and fertilization of mouse eggs in vitro. J. exp. Zool. 175, 271-282. Downloaded from Bioscientifica.com at 04/26/2023 08:51:32AM 
Kaufman, M.H. (1973) Parthenogenesis in the mouse. Nature, Lond. 242, 475-476.

Krishna, M. \& Generoso, W.M. (1977) Timing of sperm penetration, pronuclear formation, pronuclear DNA synthesis and first cleavage in naturally ovulated mouse eggs. J. exp. Zool. 202, 245-252.

Maudlin, I. \& Fraser, L.R. (1977) The effect of PMSG dose on the incidence of chromosomal anomalies in mouse embryos fertilized in vitro. J. Reprod. Fert. 50, 275-280.

MeGaughey, R.W. \& Chang, M.C. (1969) Meiosis of mouse eggs before and after sperm penetration. $J$. exp. Zool. 170, 397-410.

Strauss, F. (1956) The time and place of fertilization of the golden hamster egg. J. Embryol. exp. Morph. 4, 42-56.

Thibault, C., Gérard, M. \& Menezo, Y. (1975) Acquisition par l'ovocyte de lapine et de veau du facteur de décondensation du noyau du spermatozoide fécondant (MPGF). Annls Biol. anim. Biochim. Biophys. 15, 705-715.

Toyoda, Y., Yokoyama, M. \& Hosi, T. (1971) Studies on the fertilization of mouse eggs in vitro. II. Effects of in-vitro pre-incubation of spermatozoa on time of sperm penetration of mouse eggs in vitro. Jap. J. anim. Reprod. 16, 152-157.

Usui, N. \& Yanagimachi, R. (1976) Behavior of hamster sperm nuclei incorporated into eggs at various stages of maturation, fertilization and early development. $J$. Ultrastruct. Res. 57, 276-288.

Warnes, G.M., Moor, R.M. \& Johnson, M.H. (1977) Changes in protein synthesis during maturation of sheep oocytes in vivo and in vitro. J. Reprod. Fert. 49, 331-335.

Yanagimachi, R. (1966) Time and process of sperm penetration into hamster ova in vivo and in vitro. $J$. Reprod. Fert. 11, 359-370.

Zamboni, L. (1970) Ultrastructure of mammalian oocytes and ova. Biol. Reprod. (Suppl.) 2, 44-63.

Received 27 May 1978 